\title{
IMPLEMENTASI PENDIDIKAN MULTIKULTURAL DALAM PROSES PEMBELAJARAN DI PONDOK PESANTREN AL-MUAYYAD SURAKARTA TAHUN PELAJARAN 2017/2018
}

\author{
Oleh: \\ Nafis Nailil Hidayah ${ }^{1}$
}

\begin{abstract}
Abstrak
Pendidikan, khususnya pendidikan Islam, dengan paradigma pluralis-multikultural, menjadi kebutuhan yang mendesak untuk segera didesain dalam proses pembelajaran. Dunia pesantren dengan sisi positif negatifnya tentu bukan hal yang asing lagi. Sering terdengar bahwa pesantren merupakan ajang melunturkan rasa nasionalisme pada jiwa generasi muda. Lantas bagaimanakah implementasi pendidikan multikultural dalam proses belajar di pondok pesantren, dan bagaimanakah implementasi pendidikan multikultural dapat meningkatkan nasionalisme peserta didik di pondok pesantren? Pendidikan pluralis-multikultural merupakan pendidikan yang memberikan penekanan terhadap proses penanaman cara hidup yang harmonis. Penelitian ini berjenis penelitian kualitatif dengan strategi pendekatan fenomenologi. Sumber data berasal dari para guru, siswa SMA dan MA AL-Muayyad serta pengurus yayasan Pondok Pesantren AL-Muayyad Surakarta. Hasil penelitian ini menunjukkan bahwa (1) Tingkat penguasaan materi siswa dalam mata pelajaran PPKN, Sosiologi dan Aswaja dalam kategori baik, sehingga penerapan pendidikan multikultural telah mencapai harapan para guru. (2) implementasi pendidikan multikultural banyak terkandung didalam pelajaran PPKN, Sosiologi dan Aswaja yaitu terkandung nilai demokratis, toleransi dan humanis. (3) Dalam lingkungan pondok pesantren strategi pembiasaan adalah hal yang dirasa tepat dalam meningkatkan penanaman pendidikan multikultural melalui keseharian para siswa. Dengan demikian dapat disimpulkan implementasi pendidikan multicultural dapat menjadi alternative dalam meningkatkan jiwa nasionalisme peserta didik Pondok Pesantren Al-Muayyad Surakarta.
\end{abstract}

Kata kunci : pendidikan multikultural; pesantren

\footnotetext{
${ }^{1}$ Staff Pengajar di SMA AL-MUAYYAD Surakarta, email (nafisnaililh@gmail.com)
} 


\section{PENDAHULUAN}

Pendidikan merupakan sesuatu yang sangat vital bagi kehidupan manusia, terutama bagi pembentukan karakter sebuah peradaban dan kemajuan suatu bangsa. Pendidikan merupakan salah satu media yang paling efektif untuk melahirkan generasi yang memiliki pandangan yang mampu menjadikan keragaman sebagai bagian dari pemersatu bangsa. Pendidikan, khususnya pendidikan Islam, dengan paradigma pluralismultikultural, menjadi kebutuhan yang mendesak untuk segera dirumuskan dan didesain dalam proses pembelajaran. Karena bagaimanapun juga, pendidikan multikultural memiliki kontribusi dan nilai yang signifikan untuk membangun pemahaman dan juga kesadaran terhadap nilai-nilai pluralitas dan multikulturalitas.

Indonesia memiliki sejarah kelam kaitannya dengan konflik dan kekerasan, mulai dari kasus Ambon, Papua, Aceh, dan berbagai sejenis lainnya. Dengan beragam faktor pemicu, sesama anak bangsa Indonesia yang sama-sama beragama saling bunuh. Sampai saat ini masih banyak rentetan konflik yang masih saja terjadi. Jika dicari benang merah atas kasus yang terjadi di tanah Indonesia, dari sebagian konflik dan kekerasan yang ada, "agama" dinilai menjadi salah satu faktor yang ikut andil sebagai pemicu konflik. Salah satu fenomena yang menggambarkan konflik didalam beragama yakni konflik yang terjadi di Madura antara kaum Sunny dan Syiah.

Walaupun tidak ada agama yang mengajarkan kekerasan apalagi konflik, namun fakta tidak bisa menutup mata melihat kenyataan bahwa agama sering dikesankan dengan wajah kekerasan. Keterlibatan agama sebagai pemicu terjadinya konflik tentu menimbulkan tanda tanya, sebab agama diturunkan justru membawa pesan ketuhanan dan kemanusiaan yang sama, meskipun jenis agamanya berbeda. Dimana salah satu pesan yang ditekankan oleh semua agama di dunia adalah pentingnya penciptaan perdamaian berdasarkan prinsip persamaan dan kesatuan manusia.

Di era modernisasi seperti saat ini, dunia pendidikan sangatlah berkembang dengan pesatnya. Entah itu pendidikan formal maupun non formal. Salah satunya yaitu berkembangnya Islamic boarding school yang menerapkan metode pesantren didalam kurikulum pembelajarannya. Siswa yang berasal dari latar belakang budaya yang beragam untuk sementara waktu selama masa studi diwajibkan untuk menetap di asrama. Hal ini diberlakukan agar siswa dapat lebih fokus dalam menuntut ilmu. Pantauan 24 jam oleh pihak penyelenggara pendidikan, mengakibatkan siswa tidak dapat mengenal banyak dunia luar, karena ruang gerak untuk 
bersosialisasipun telah dibatasi sedemikian rupa. Sehingga kegiatan siswa didalam keseharian pesantrenpun hanya untuk belajar dan mengaji, tanpa ada kesempatan untuk merubah pola hidup mereka.

Dunia pesantren dengan sisi positif negatifnya tentu bukan hal yang asing lagi. Banyak sisi positif yang dapat diperoleh yaitu salah satunya menjadikan putra putri bangsa Indonesia berakhlaqul karimah. Harapannya dengan karakter yang kuat putra-putri Indonesia dapat meneruskan perjuangan bangsa kedepan. Berbicara sisi negatif, sering kita dengar bahwa pesantren merupakan ajang melunturkan jiwa nasionalisme pada jiwa pemuda Indonesia. Ungkapan tersebut sering diperdebatkan oleh beberapa kelompok masyarakat. Masyarakat luar memandang dunia pesantren kental dengan kehidupan rohani, mengindikasikan bahwa didalam pesantren tidak ditanamkannya jiwa nasionalisme terhadap peserta didik, bahkan sempat beredar isu bahwa pesantren adalah sarang teroris yang akan memecah belah bangsa Indonesia. Pesantren dianggap menanamkan untuk berjihad dengan membunuh kaum kafir dalam artian kaum non muslim. Hal ini menjadi pertanyaan banyak pihak, bagaimana kaum pesantren dalam menyikapi multikultural bangsa Indonesia dikarenakan pada era saat ini menjadikan model pendidikan Islam pluralitasmultikultural sebagai bagian dari proses pembelajaran menjadi sebuah kebutuhan yang tidak terelakkan lagi.

Berdasarkan kenyataan yang memilukan ini, maka keberadaan pendidikan multikultural sangat diperlukan. Menurut Ainul Yaqin ( 2005 : 25) "pendidikan multikultural adalah strategi pendidikan yang diaplikasikan pada semua jenis mata pelajaran dengan cara menggunakan perbedaanperbedaan cultural yang ada pada para siswa seperti perbedaan etnis, agama, bahasa, gender, klas sosial, ras, kemampuan, dan umur agar proses belajar menjadi efektif dan mudah." Keragaman tersebut berpengaruh langsung terhadap kemampuan guru dalam melaksanakan kurikulum. Kemampuan sekolah dalam menyediakan pengalaman belajar serta berpengaruh dalam mengolah informasi menjadi sesuatu yang dapat diterjemahkan sebagai hasil belajar. Keragaman itu menjadi variable bebas yang memiliki kontribusi sangat signifikan terhadap keberhasilan implementasi kurikulum yang ada, baik kurikulum sebagai proses maupun kurikulum sebagai hasil. Oleh karena itu, keragaman tersebut harus menjadi factor yang seyogianya diperhitungkan dan dipertimbangkan dalam penentuan filsafat, teori, visi, pengembangan dokumen, sosialisasi, dan pelaksanaan kurikulum.

Pendidikan pluralis-multikultural merupakan pendidikan yang memberikan penekanan terhadap proses penanaman cara hidup yang harmonis. Bangsa Indonesia dapat 
mewujudkan sikap saling menghormati, tulus, dan toleran terhadap keanekaragaman budaya yang hidup di tengah-tengah masyarakat dengan tingkat pluralitas yang tinggi. Dengan pendidikan pluralis-multikultural, diharapkan akan lahir kesadaran dan pemahaman secara luas. Hal ini dapat diwujudkan dalam sikap yang toleran, bukan sikap yang kaku, eksklusif, dan menafikan eksistensi kelompok lain maupun mereka yang berbeda, apa pun bentuk perbedaannya. Dalam konteks Indonesia yang sarat dengan kemajemukan, pendidikan pluralis-multikultural memliki peranan yang sangat strategis untuk dapat mengelola kemajemukan secara kreatif.

Berdasarkan latar belakang tersebut, peneliti tertarik untuk mediskripsikan pendidikan multikultural yang saat ini mulai digalakkan disekolah, terutama di sekolahsekolah yang berbasis agama atau pesantren (Islamic boarding school). Untuk itu, peneliti menyusun penelitian pendidikan multicultural ini dengan judul "Implementasi Pendidikan Multikultural Dalam Proses Pembelajaran di Pondok Pesantren AL-MUAYYAD Surakarta Tahun Pelajaran 2017/2018”.

Batasan masalah yang dikaji dalam penelitian ini adalah implementasi pendidikan multikultural dalam proses pembelajaran di Pondok Pesantren AL-MUAYYAD Surakarta Tahun Pelajaran 2017/2018.
Sejalan dengan batasan masalah tersebut, masalah penelitian ini dirumuskan menjadi :

"Bagaimana implementasi pendidikan multicultural di lingkungan Pondok Pesantren AL-Muayyad Surakarta pada tahun pelajaran 2017/2018?"

Tujuan penelitian ini adalah untuk menggali informasi serta data mengenai pelaksanaan konsep pendidikan multikultural dalam kegiatan pembelajaran di Pondok Pesantren AL-Muayyad Surakarta tahun pelajaran 2017/2018.

Penelitian tentang implementasi pendidikan multicultural ini bermanfaat dalam hal berikut. Diharapkan penelitian ini dapat memberi kontribusi bagi para pendidik berupa pengintegrasian konsep pendidikan multikultural di silabus dan Rancangan Pelaksanaan Pembelajaran yang nantinya diaplikasikan di dalam proses belajar mengajar didalam kelas maupun diluar kelas. selain itu juga membantu peserta didik agar dapat mengaplikasikan konsep pendidikan multikultural di kehidupan sehari-hari yang akan membentuk watak bangsa Indonesia.

Penelitian ini tidak dapat lahir tanpa penelitian-penelitian sebelumnya. Diantaranya adalah penelitian yang dilakukan oleh Tatang M. Amirin (2012) dalam jurnalnya dengan judul "Implementasi Pendekatan Pendidikan Multikultural Konstektual Berbasis Kearifan Lokal Di Indonesia." Menyatakan Tujuan 
utama penerapan pendekatan pendidikan multikultural di tingkat nasional hendaknya dititikberatkan pada pemahaman dan penghargaan peserta didik terhadap budayanya sendiri dan budaya orang lain, mencakup agama, berlandaskan semboyan bhineka tunggal ika serta Pancasila. Untuk itu maka diperlukan adanya penataan ulang dan penguatan pendidikan kewarganegaraan (PKn), IPS, dan pendidikan agama dengan memasukkan muatan materi keanekaragaman nilai-budaya, didukung oleh penelitian sosiologis dan antropologis untuk pendidikan. Di tingkat daerah atau lokal, pendekatan pendidikan multikultural seyogyanya diterapkan secara kontekstual, dengan menggunakan "kearifan lokal" membangun pemahaman dan saling menghargai perbedaan nilai budaya dan asal-usul etnisitas dan atau suku bangsa sesuai dengan keadaan setempat. Penelitian mengenai perbedaan nilai budaya setempat seyogyanya dilakukan oleh para pejabat pendidikan setempat dan guru dan atau pengajar universitas untuk dapat digunakan secara bijak dalam pengembangan struktur dan kultur sekolah dan kegiatan belajar-mengajar dan bimbingan di dalamnya.

Selanjutnya adalah penelitian yang dilakukan oleh Akhmad Hidayatullah Al Arifin (2012) dalam jurnalnya dengan judul "Implementasi Pendidikan Multikultural Dalam Praksis Pendidikan Di Indonesia". Menyatakan bahwa Pendidikan multikultural merupakan suatu pendekatan progresif untuk melakukan transformasi pendidikan yang secara holistik memberikan kritik dan menunjukkan kelemahan-kelemahan, kegagalankegagalan dan diskrimainasi di dunia pendidikan. Pendidikan multikultural sebagai instrumen rekayasa sosial mendorong sekolah supaya dapat berperan dalam menanamkan kesadaran dalam masyarakat multikultur dan mengembangkan sikap tenggang rasa dan toleran utuk mewujudkan kebutuhan serta kemampuan bekerjasama dengan segala perbedaan yang ada. Artikel berusaha menunjukkan bahwa praktek pendidikan multikultural di Indonesia dapat dilaksanakan secara fleksibel, tidak harus dalam bentuk mata pelajaran yang terpisah atau monolitik. Pelaksanaan pendidikan multikultural didasarkan atas lima dimensi: (1) integrasi konten, (2) proses penyusunan pengetahuan, (3) mengurangi prasangka, (4) pedagogi setara, serta (5) budaya sekolah dan struktur sekolah yang memberdayakan.

Dari beberapa penelitian tersebut dapat dianalisis bahwa pendidikan multikultural merupakan suatu pendekatan progresif untuk melakukan transformasi pendidikan, memiliki banyak kajian permasalahan yang menarik untuk diteliti. Penelitian yang mengangkat topik pendidikan multikultural dalam proses pembelajaran di Pondok Pesantren masih jarang diteliti, sehingga peneliti berasumsi penelitian ini menjadi tunas penelitian pendidikan multicultural dalam aspek pendidikan pondok pesantren. 
Sebuah penelitian tidak dapat berdiri tanpa teori yang menyangganya. Oleh sebab itu, peneliti melakukan riset dengan landasan teori berikut:

\section{Pendidikan Multikultural}

Dalam konsep multikulturalisme, terdapat kaitan yang erat bagi pembentukan masyarakat yang berlandaskan bhineka tunggal ika serta mewujudkan suatu kebudayaan nasional yang menjadi pemersatu bagi bangsa Indonesia. Zamroni (2011144)"mendefinisikan pendidikan multikultural sebagai suatu pendekatan progresif untuk melakukan transformasi pendidikan yang secara holistik memberikan kritik dan menunjukkan kelemahan-kelemahan, kegagalan-kegagalan dan diskriminasi yang terjadi di dalam dunia pendidikan". Namun, dalam pelaksanaannya masih terdapat berbagai hambatan yang menghalangi terbentuknya multikulturalisme di masyarakat. Hal tersebut menjadi pekerjaan rumah para ilmuan untuk memecahkan persoalan yang terdapat didalam dunia pendidikan dengan tujuan kegagalan-kegagalan serta kelemahankelamahan bahkan diskriminasi dalam dunia pendidikan dapat benar-benar diungkap.

Sementara Ainurrafiq Dawam (2003:100) menjelaskan bahwa "pendidikan multikultural adalah proses pengembangan seluruh potensi manusia yang menghargai pluralitas dan heterogenitasnya sebagai konsekuensi keragaman budaya, etnis,suku, dan aliran (agama). Pengertian pendidikan multikultural yang demikian tentu mempunyai implikasi yang sangat luas dalam pendidikan. Karena pendidikan itu sendiri secara umum dipahami sebagai proses tanpa akhir atau proses sepanjang hayat. Dengan demikian, pendidikan multikultural menghendaki penghormatan dan penghargaan setinggitingginya terhadap harkat dan martabat manusia dari manapun dia datangnya dan berbudaya apapun dia.

Mengenai fokus pendidikan multikultural, H.A.R. Tilaar (2004: 297) mengungkapkan bahwa dalam program pendidikan multikultural, fokus tidak lagi diarahkan semata-mata kepada kelompok rasial, agama dan kultural domain atau mainstream. Fokus seperti ini pernah menjadi tekanan pada pendidikan interkultural yang menekankan peningkatan pemahaman dan toleransi individu-individu yang berasal dari kelompok minoritas terhadap budaya mainstream yang dominan, yang pada akhirnya menyebabkan orang-orang dari kelompok minoritas terintegrasi ke dalam masyarakat mainstream. Pendidikan multikultural sebenarnya merupakan sikap "peduli" dan mau mengerti (difference), atau "politics of recognition" politik pengakuan terhadap orang-orang dari kelompok minoritas.

Dari uraian di atas penulis dapat memberi kesimpulan bahwa pendidikan 
multikultural mempunyai makna pendidikan yang mempunyai visi dapat membuka cakrawala yang lebih luas serta mampu untuk melintas batas kelompok etnis atau tradisi budaya dan agama sendiri, sehingga harapannya mampu melihat kemanusiaan sebagai sebuah keluarga yang memiliki perbedaan maupun kesamaan cita-cita. Disinilah pendidikan yang sesungguhnya akan nilai-nilai dasar kemanusiaan untuk perdamaian, kemerdekaan, dan solidaritas.

\section{a. Pendidikan Multikultural sebagai pendidikan kritis}

Dengan banyaknya persoalan yang muncul di masyarakat Indonesia sebagai krisis budaya seperti disintegrasi sosial-politik yang bersumber dari euphoria kebebasan yang nyaris keblabasan, lenyapnya kesabaran sosial sehingga mudah mengamuk dan melakukan berbagai tindakan kekerasan dan anarki, merosotnya penghargaan dan kepatuhan terhadap hukum, etika, moral, dan kesantunan sosial, semakin meluasnya penyakit-penyakit sosial lainnya, berlanjutnya konflik dan kekerasan yang bernuansa politis, etnis dan agama seperti yang pernah terjadi di berbagai wilayah Indonesia menjadi urgensi pekerjaan rumah untuk pemerintah Indonesia.

Koesoema,(2007:160) "Maka lembaga pendidikan pun dipilih oleh pemerintah untuk membentuk karakter bangsa Indonesia, terutama para peserta didik. Kalangan pendidikan khususnya melihat bahwa pendidikan karakter adalah suatu pendidikan kritis yang dibuat untuk masyarakat pada umumnya dan peserta didik pada khususnya untuk melihat situasi dan kondisi buadaya Indonesia saat ini. Karena peserta didik adalah generasi yang diharapkan dapat menjadi tumpuan untuk kemajuan bangsa Indonesia". Dengan demikian peran guru atau pendidik pun menjadi sesuatu yang sentral atau penting, karena peran pendidik adalah menanamkan nilai-nilai multikulturalisme. Diharapkan dengan munculnya pendidikan multicultural sebagai pendidikan kritis dari masyarakat kalangan pendidikan dapat mengatasi persoalan budaya dan karakter yang melanda bangsa Indonesia saat ini.

\section{b. Pendidikan Multikultural sebagai pendidikan konstruktif}

Asal kata konstruktivisme adalah "to construct" yang artinya membangun atau menyusun. Menurut Carin (dalam Anggriamurti, 2009:175) bahwa teori konstruktivisme adalah suatu teori belajar yang menekankan bahwa para siswa sebagai pembelajar tidak menerima begitu saja pengetahuan yang mereka dapatkan, tetapi mereka secara aktif membangun pengetahuan secara individual. Menurut Von Glasersfeld (dalam Anggriamurti, 2009:176) bahwa konstruktivisme adalah salah satu filsafat pengetahuan yang menekankan bahwa pengetahuan kita adalah konstruksi (bentukan) kita sendiri. Pengetahuan itu dibentuk oleh struktur konsepsi seseorang sewaktu 
berinteraksi dengan lingkungannya yang berkaitan dengan nilai multikultural.

Teori Konstruktivisme didefinisikan sebagai pembelajaran yang bersifat generatif, yaitu tindakan mencipta sesuatu makna dari apa yang dipelajari. Beda dengan aliran behavioristik yang memahami hakikat belajar sebagai kegiatan yang bersifat mekanistik antara stimulus respon, kontruktivisme lebih memahami belajar sebagai kegiatan manusia membangun atau menciptakan pengetahuan dengan memberi makna pada pengetahuannya sesuai dengan pengalamanya.

Secara garis besar, prinsip-prinsip Konstruktivisme yang diterapkan dalam belajar mengajar adalah:

a. Pengetahuan dibangun oleh siswa sendiri.

b. Pengetahuan tidak dapat dipindahkan dari guru ke murid, kecuali hanya dengan keaktifan murid sendiri untuk menalar.

c. Murid aktif megkonstruksi secara terus menerus, sehingga selalu terjadi perubahan konsep ilmiah.

d. Guru sekedar membantu menyediakan saran dan situasi agar proses konstruksi berjalan lancar.

e. Menghadapi masalah yang relevan dengan siswa.

f. Struktur pembelajaran seputar konsep utama pentingnya sebuah pertanyaan.

g. Mencari dan menilai pendapat siswa.

h. Menyesuaikan kurikulum untuk menanggapi anggapan siswa.
Dari semua itu hanya ada satu prinsip yang paling penting adalah guru tidak boleh hanya semata-mata memberikan pengetahuan kepada siswa. siswa harus membangun pengetahuan didalam benaknya sendiri. Seorang guru dapat membantu proses ini dengan cara-cara mengajar yang membuat informasi menjadi sangat bermakna dan sangat relevan bagi siswa, dengan memberikan kesempatan kepada siswa untuk menemukan atau menerapkan sendiri ide-ide dan dengan mengajak siswa agar menyadari dan menggunakan strategi-strategi mereka sendiri untuk belajar tentang keberagaman bangsa Indonesia. Guru dapat memberikan tangga kepada siswa yang mana tangga itu nantinya dimaksudkan dapat membantu mereka mencapai tingkat penemuan hakikat dari multikultural.

Dalam teori pembelajaran konstruktivisme, anak dituntut agar mampu mengembangkan dirinya sendiri, guru hanya memberikan sedikit stimulus kepada anak. Perbandingan antara teori pembelajaran konstruktivisme. Pada teori konstriktivisme lebih menekankan pada keterlibatan siswa dalam kegiatan pembelajaran, baik secara fisik, mental dan emosional. Penerapan teori ini cocok digunakan pada materi yang berhubungan langsung pada proses berpikir secara abstrak, misalnya keberagaman bangsa Indonesia. Sedangkan pada teori humanisme, siswa benar-benar diajak dan dituntut untuk 
mengembangkan diri dalam kegiatan pembelajaran. Dapat dikatakan dengan "mereka butuh, mereka yang mencari". Jadi dalam teori ini guru hanya sebagai fasilitator saja. Pembelajaran berdasarkan pada teori humanisme cocok diterapkan pada materi yang sifatnya mampu membentuk kepribadian, hati nurani, perubahan sikap, dan analisis terhadap fenomena sosial. Teori kontruktivisme adalah sebagai pembelajaran yang bersifat generatif, yaitu tindakan mencipta sesuatu makna dari apa yang dipelajari. Peran guru dalam pembelajaran multikultural menurut teori kontruktivisme adalah sebagai fasilitator atau moderator. Teori konstruktivistik merupakan pengembangan dari teori belajar kognitif. Piaget menyatakan bahwa "ilmu pengetahuan dibangun dalam pikiran seorang anak dengan kegiatan asimilasi dan akomodasi sesuai dengan skemata yang dimilikinya."

\section{METODOLOGI}

\subsection{Metode Pengambilan Data}

Metode pengambilan data yang digunakan adalah metode kualitatif sehingga data yang diperoleh merupakan pernyataan alami narasumber dan wawancara. Dengan Strategi fenomenologi peneliti menggali data bagaimana para informan mendeskripsikan pemahaman dan pelaksanaan pendidikan multikultural dalam proses pembelajaran disekolahnya dan peneliti mengintepretasikannya sesuai dengan fenomena atau permasalahan yang ada dalam proses pelaksanaan konsep pendidikan multicultural tersebut.

\subsection{Sumber Data}

Adapun informan dalam penelitian ini adalah warga sekolah SMA Al-Muayyad Surakarta Tahun Pelajaran 2013/2014 dan ahli pendidikan terutama yang paham tentang pendidikan Multikultural yaitu :

1) Kepala Sekolah SMA Al-Muayyad Surakarta yang berperan sebagai pihak managerial sekolah. Sehingga peneliti dapat mengetahui data dari informan bagaimana proses implementasi pendidikan karakter itu dalam kegiatan belajar dikelas maupun diluar kelas.

2) Pengurus Sekolah yaitu Wakasek kurikulum yang bertugas untuk menentukan kurikulum yang berkaitan dengan program kerja yang berkaitan dengan pendidikan multikultural.

3) Guru-guru mata pelajaran tertentu, diantaranya guru mata pelajaran $\mathrm{PKN}$, Sosiologi, Bimbingan konseling dan ASWAJA karena tidak semua guru dapat menjelaskan proses penanaman nilai multikultural di dalam kelas sesuai dengan materi pelajaran yang diajarkan kepada siswa.

4) Murid SMA dan MA Pondok Pesantren AL-Muayyad Al-Muayyad Surakarta Tahun Pelajaran 2017/2018 klas X dan XI. Alasan mereka menjadi informan adalah untuk membantu peneliti mendapatkan data 
relevan dengan penelitian yang sedang dilakukan yang berkaitan dengan implementasi pendidikan multicultural di lingkungan Pondok Pesantren Al- Muayyad Surakarta.

\subsection{Waktu Penelitian}

Penelitian ini dilaksanakan selama dua minggu, dimulai dengan kegiatan observasi pada 13 dan 14 September 2017 hingga analisis data yang selesai pada 30 September 2017.

\subsection{Teknik Pengumpulan Data}

Dalam penelitian ini tekhnik yang tepat dalam mengambil data adalah wawancara serta observasi. Wawancara dilakukan dengan bebas dengan suasana informal dan pertanyaan tidak terstruktur namun tetap mengarah pada fokuus masalah penelitian. wawancara dilakukan dengan para guru-guru mata pelajaran tertentu, kepala sekolah, pengurus sekolah, serta para siswa dan ahli di bidang pendidikan, wawancara dipilih karena untuk memperoleh informasi sesuai fokus penelitian yaitu pemahaman para guru dan para siswa tentang pendidikan multikultural serta implementasi konsep pendidikan multikultural disekolah dalam kegiatan pembelajaran tersebut. Peneliti mencatat informasi yang diberikan oleh informan dan mendiskusikan yang belum jelas tanpa memberikan pengaruh terhadap informan mengenai jawaban yang diberikan.
Observasi dilakukan sebelum pengambilan data. Hasil observasi didiskripsikan untuk pemetaan data dan penentuan tindakan penelitian. Dalam kegiatan observasi, peneliti berperan sebagai pengamat. Kegiatan wawancara dilakukan untuk pengambilan data riil. Wawancara dilakukan kepada guru-guru mata pelajaran tertentu, kepala sekolah, pengurus sekolah, serta para siswa dan pengurus yayasan pondok pesantren yang menjadi responden. Data yang diperoleh dari wawancara dianalisis, kemudian dideskripsikan.

\section{Pembahasan Hasil Penelitian}

\section{Pemahaman tentang Pendidikan Mulitikultural.}

Berdasarkan hasil wawancara peneliti dengan informan, peneliti memperolah data yang beragam tentang pemahaman pendidikan multicultural. Pemahaman tentang pendidikan multikultural pun menjadi beragam antara lain dari salah satu pimpinan sekolah mendefinisikan bahwa, "Pendidikan multikultural adalah suatu system penanaman nilai-nilai untuk membentuk karakter warga sekolah untuk menjalankan nilai-nilai yang baik dan luhur saling toleransi, saling menghormati dan saling menghargai diatas perbedaan untuk terwujudnya kehidupan yang damai dan sejahtera. " (KS/SR/13/09/2017). Menurut informan pendidikan multikultural adalah penanaman nilai-nilai untuk 
membentuk karakter yang dan luhur dimana tercipta suasana yang damai dengan saling toleransi, menghargai dan saling menghormati mengingat Negara Indonesia ini adalah Negara yang multikultur terdiri dari berbagai macam budaya, bahasa, agama, keyakinan dan lain sebagainya. Jika perbeda-perbedaan tersebut tidak terkelola dengan baik maka akan menjadi bomerang bagi warga Negara Indonesia sendiri, karena akan banyak memicu terjadinya konflik yang dapat memecah belah persatuan bangsa.

Pendapat diatas didukung oleh pernyataan ketua yayasan bahwasanya pendidikan multikultural adalah "sebuah gagasan untuk mengamalkan amalan didalam aqidah islamiyah selain hablumminallah manusia didunia juga harus hablumminnas dengan pendidikan yang mengakui perbedaan untuk saling menghargai diatas perbedaan maka yang menjadi tujuan bersama adalah kedamaian." (KY/AR/14/09/2017).

Pernyataan dari bapak Kiai Pondok Pesantren Al-Muayyad tersebut bisa kita artikan bahwa untuk menjadi manusia yang beriman diharuskan untuk mengamalkan amalan aqidah islamiyah. Amalan yang terdapat didalam aqidah islamiyah salah satunya yakni manusia diwajibkan selain untuk hablumminallah juga hablumminnas yakni berhubungan baik dengan manusia. Menjaga hubungan baik dengan sesama manusia bisa dilakukan dengan cara menjaga toleransi antar agama, saling menghargai serta saling menghormati.

Berbeda dengan salah satu informan yang mengajarkan mata pelajaran Sosiologi di dalam kelas X menyebutkan bahwa, “memberi pengetahuan kepada peserta didik bahwa bangsa Indonesia adalah masyarakat yang multikultur, dalam artian terdiri dari berbagai macam hal yang berbeda-beda, nah dari sini kita harus bisa memecahkan bersama bagaimana Indonesia tetap bersatu meskipun berbeda-beda, ini yang harus difikirkan oleh siswa." (GR/ASR/13/09/2017). Jadi menurut informan selaku guru di kelas mendefinisikan pendidikan multikultural adalah suatu alat untuk memberi pemahaman terhadap siswa bagaimana kondisi Indonesia. Selain itu informan mengajak para siswa untuk turut serta berkontribusi dalam mencari solusi atas permasalahan yang dihadapi oleh bangsa Indonesia yang dilatar belakangi oleh perbedaan. Dengan begitu secara tidak langsung informan memiliki makna untuk menanamkan pendidikan karakter terhadap siswa.

Adapun pendapat dari guru mata pelajaran kewarganegaraan mendefinisikan bahwa " Pendidikan multicultural secara khususnya adalah pendidikan untuk membentuk suatu kepribadian anak yang memiliki jiwa toleransi tinggi, menghargai dan menghormati akan sesuatu yang berbeda dengan dirinya". (GR/ATK/13/09/2017). Jadi menurut informan pendidikan multikultural 
terutama dalam mata pelajaran kewarganegaraan ini tentu sangat menekankan semangat kebangsaan, cinta tanah air, dan berjuang dalam menjaga perdamaian. Dengan mata pelajaran yang diajarkan oleh informan sehingga dalam pelaksanaannya pun yang ditekankan adalah semangat kebangsaan untuk menjaga perdamaian dan keutuhan NKRI.

Menurut siswa pun berbeda dalam pemahaman pendidikan multikultural. Seperti diungkapkan siswi kelas $\mathrm{X}$ "Pendidikan multikultural itu menurut saya mba, ya usaha untuk menyatukan perbadaan dengan perdamaian gitu, seperti dipondok ini saya orang solo harus menjaga sikap dan toleransi untuk menghargai teman-teman saya yang dari luar jawa agar tidak terjadi konflik." (S/FA/12/09/2017). Jadi bagi siswa pendidikan multikultural adalah usaha untuk mencegah terjadinya konflik sehingga dalam bersosialisasi dan hidup bersama didalam pesantren harus pandai menjaga sikap agar supaya perdamaian tetap terjaga.

Jadi pendidikan multikultural adalah suatu upaya membentuk karakter manusia, dan hal tersebut menjadi penting untuk watak atau kepribadian peserta didik. Dapat dilihat bahwa pemahaman kepala sekolah, guru, siswa,dan warga sekolah lainnya mengacu pada tata tertib serta budaya sekolah yang dapat membentuk karakter siswa agar bisa menjadi siswa siap jika nantinya terjun kedalam masyarakat. Selain itu pula terdapat kolaborasi yang baik dan solid antara elemen sekolah yang menjadi kesatuan utuh dalam membentuk karakter multikulturalis bangsa Indonesia.

\section{II.Pelaksanaan Pendidikan Multikultural}

Pelaksanaan pendidikan multikultural yang dilakukan oleh para guru dilakukan saat penyusunan perangkat pembelajaran yaitu RPP dan Silabus dengan menyisipkan nilainilai multikulturalis antara lain demokratis, toleransi, jujur, kreatif, dan lain-lain.Setelah dievaluasi melalui tim yang ditunjuk oleh kepala sekolah sebagai tim evaluasi, dan jika sudah selesai di evaluasi oleh tim maka kepala sekolah akan mengevaluasi tim tersebut malalui briefing. Kepala sekolah pun sering berkomunikasi untuk memberi arahan kepada para warga sekolah terutama dewan guru, “untuk pembuatan RPP maupun Silabus, kami selalu mensosialisasi jika ada peraturan baru, dengan cara kami beri contoh sebagai panduan, bahkan dalam bentuk soft file sehingga para guru lebih mudah dalam menyaring mana yang diperlukan dan mana yang tidak perlu" (KS/SR/13/09/2017). Namun dalam kenyataannya yang ditemukan oleh peneliti saat observasi dan wawancara dengan guru mata pelajaran tidak semua informan sudah mencamtumkan nilai karakter dalam RPP dan Silabus.

Hanya guru-guru tertentu yang mencantumkan nilai karakter dalam RPP dan Silabus yaitu informan yang menjadi guru 
sosiologi kelas kelas XI dan guru Aswaja. Seperti yang diungkapkan oleh informan, "penerapan nilai karakter multikultural itu saya terapkan sesuai di RPP dan silabus baru saya aplikasikan kelas mba" (GR/ATK/13/09/2017). Sehingga dengan adanya Silabus dan RPP maka kegiatan pembelajaran dapat berlangsung secara sistematis sesuai dengan harapan. Oleh karena itu bisa ditinjau mengenai waktu, media dan metode yang digunakan oleh masing-masing guru dikelas. Tujuan dari hal tersebut untuk mempermudah proses evaluasi dikelas, yang nantinya dijadikan tolak ukur sebagai penerapan model pembelajaran ditahun berikutnya.

Mengenai waktu pelaksanaan pengimplementasian pendidikan multicultural di pondok pesantren Al-Muayyad Surakarta sebenarnya bisa dikatakan hampir 24 jam perhari. Hal ini dikarenakan siswa dan siswi SMA Al-Muayyad Surakarta wajib untuk tinggal di asrama selama masa pendidikan hingga di nyatakan lulus. Dengan latar belakang siswa siswi yang berasal dari berbagai macam latar belakang budaya dan ditempatkan dalam satu ruangan maka hal ini dapat menjadi media bagi siswa untuk secara langsung mengaplikasikan pendidikan multikultural dalam keseharian mereka. Dimulai dari bangun tidur siswa-siswa diajarkan untuk displin serta saling menghargai dimana dalam segala hal dibiasakan mengantri, dari mengantri kamar mandi, mengantri mengaji, mengantri sarapan dan lain sebagainya. " semua santri (sebutan siswa siswi di asrama) disini semua diperlakukan sama mbak, kalau dia melanggar peraturan ya kami tindak lanjuti tidak perduli anak siapa, "(PY/KH/14/09/2017). Pengurus yayasan disini bagaimana caranya siswa- siswi di latih untuk tidak egois dan bersikap semaunya sendiri dengan metode menerapkan kedisiplinan. Karena pihak yayasan menganggap siswa-siswi semua sama rata, tidak mempedulikan ia putra menteri atau putra kiai semua harus berlatih sabar dan menghargai teman yang lebih dahulu mendapat antrian, dan siapa yang salah maka ia yang harus bertanggung jawab.

Mata pelajaran yang berkaitan dengan pendidikan multikulturalisme yakni sosiologi dan materi yang disusun oleh pihak sekolah sendiri yakni ASWAJA. Untuk sosiologi waktu untuk mengajarkan materi multikulturalisme yaitu didalam materi ajar kelas XI semester genap tema masyarakat multikultural. Materi ini diajarkan 3x45 menit (3x pertemuan). “untuk mata pelajar sosiologi itu lebih asyik untuk melakukan pengamatan sosial ya mbak, jadi dengan metode siswa diberi tugas untuk mencari permasalahan dan mencari solusinya dengan diskusi kelompok" (GR/ASR/13/0(/2017). Sehingga guru disini menggunakan media internet atau surat kabar sebagai rujukan bagi para siswa untuk mencari tugas dari guru. Untuk metode guru lebih 
memilih diskusi kelompok karena dengan begitu dirasa lebih kondusif untuk pengaplikasian pendidikan multikultural karena dengan kerja kelompok siswa dapat secara langsung berlatih bersosialisasi dengan teman-temannya.

Materi selanjutnya yaitu mata pelajaran yang dirumuskan oleh pihak sekolah sendiri yakni mata pelajaran Ahlussunah Wal Jama'ah. Mata pelajaran ini berisi materi ke $\mathrm{Nu}$ an yang secara garis besar berisi tata cara kehidupan sebagai warga Nahdlatul 'ulama. Materi ini di ajarkan 2 x 45 menit dengan metode ceramah oleh guru yang mengampu materi tersebut. Untuk media beliau banyak menggunakan contoh film documenter dengan power point dan LCD.

Selain itu masih terdapat beberapa program ekstra kurikuler yang mendukung pengimplementasian pendidikan multikultural yakni Khitobah yaitu pelatihan bagi para siswa untuk berdakwah dengan tujuan siswa memiliki mental yang kuat untuk berbicara didapan umum. Disela acara khitobah ini kepala sekolah memiliki kesempatan untuk memberikan bekal terhadap siswa, termasuk membekali siswa dengan nilai-nilai multikulturalisme. Pelatihan khitobah ini dilaksanakan $2 \mathrm{x}$ dalam satu semester. Selanjutnya ekstrakurikuler yang lain yakni AMT/AMD yakni pelatihan yang diperuntukkan untuk siswa baru agar dapat bertahan di SMA Al-Muayyad hingga selesai masa studi. Metode yang digunakan yakni beragam dari ceramah, diskusi kelompok hingga managemen konflik. Semua dilakukan unuk mencapai tujuan pembentukan mental para siswa serta menumbuhkan karakter yang kuat di dalam jiwa para siswa.

\section{Kesimpulan}

Berdasarkan deskripsi hasil penelitian dan analisis data penelitian tentang implementasi pendidikan multikultural yang dilakukan oleh pendidik di lingkungan Pondok Pesantren Al-Muayyad Surakarta Tahun Pelajaran 2017/2018, penulis dapat mengambil kesimpulan sebagai berikut:

Pendidikan multikultural dipandang dari warga Pondok Pesantren AL-Muayyad Surakarta merupakan suatu upaya membentuk karakter peserta didik. Tanpa adanya sosialisasi secara khusus mengenai pendidikan multikultural pihak sekolah sudah menyadari akan pentingnya pendidikan multikutural, sehingga telah sejak dari pertama berdiri pendidikan multikultural telah dilaksanakan. Mengenai waktu pelaksanaan pengimplementasian pendidikan multikultural di Pondok Pesantren Al-Muayyad Surakarta bisa dikatakan hampir 24 jam perhari dikarenakan adanya system pendidikan wajib asrama. Dengan demikian dapat disimpulkan implementasi pendidikan multikultural dapat menjadi alternatif dalam meningkatkan 
karakter nasionalisme peserta didik Pondok Pesantren Al-Muayyad Surakarta.

Setelah mengadakan penelitian dan pengkajian tentang implementasi pendidikan multikultural di sebuah lembaga pendidikan berbasis Islam, maka peneliti memberi saransaran sebagai berikut : Para guru hendaknya lebih inofatif menggunakan model pembelajaran di dalam kelas dan diluar kelas untuk mengimplementasikan pendidikan multikultural kepada para siswa. Selain itu pendidik harus dapat mencontohkan langsung untuk menjadi suri tauladan yang baik bagi para peserta didiknya sehingga pembentukan karakter siswa pun terlaksana dengan maksimal. Sedangkan para ustadz dan ustadzah serta pengurus asrama harus bisa menciptakan suasana kondusif untuk membentuk karakter demokratis, humanis dan pluralis.

\section{DAFTAR PUSTAKA}

Agus Salim. (2006). Teori dan Paradigma Penelitian Sosial. Yogyakarta: Tiara Wacana.

Ainul Yaqin. (2005). Pendidikan Multikultural Cross-Cultural Understanding Untuk Demokrasi Dan Keadilan. Yogyakarta : Nuansa Aksara.

Ainurrofiq Dawam. (2003). "Emoh" Sekolah Menolak "Komersialisasi Pendidikan" dan "Kanibalisme Intelektual”, Menuju Pendidikan Multikultural. Yogyakarta: Inspeal Press.

Akhmad Hidayatullah. (2012). Implementasi Pendidikan Multikultural Dalam Praksis Pendidikan Di Indonesia. Yogyakarta: Pilar Media.

Anggriamurti. (2009). Pendidikan Konstruktivisme. Bandung: Alfabeta.

Burhan Bungin. (2003). Analisis Data Penelitian Kualitatif. Jakarta : Raja Grafindo Persada.

Koesoema D.(2007). Pendidikan Karakter : Strategi Mendidik Anak di Zaman Global. Jakarta: Grasindo.

Naim Ngainun \& Achmad Sauqi. (2008). Pendidikan Multikultural Konsep dan Aplikasi. Jogjakarta : Ar-Ruzz Media.

Sutopo HB. (2002). Metodologi Penelitian Kualitatif Dasar Teori dan Terapannya Dalam Penelitian. Surakarta: Universitas Sebelas Maret.

Tilaar H.A.R (2002). Perubahan Sosial dan Pendidikan: Pengantar Pedagogik Transformatif untuk Indonesia. Jakarta: Grasindo.

Yamin M.(2009). Menggugat Pendidikan Indonesia. Belajar dari Paulo Freire dan Ki Hajdar Dewantara. Yogyakarta: Ar-Ruzz Media. 